УДК:636.8.09:616.36-008.8

doi: $10.36359 /$ scivp.2019-20-2.55

\title{
ДО ПИТАННЯ ЗАХВОРЮВАНЬ ГЕПАТОБІЛІАРНОЇ СИСТЕМИ У КОТIB
}

\author{
Н. С. Канівець, канд. вет. наук, дочент, \\ С. О. Кравченко, канд. вет. наук, дочент, \\ Т. Л. Бурда, матістр ветеринарної медицини, \\ Ю. В. Максименко ${ }^{12}$, здобувач вищої освіти СВО «Магістр» \\ Полтавська державна аграрна академія \\ вул. Г. Сковороди, 1/3, м. Полтава, 36003, Україна
}

\begin{abstract}
Недотримання власниками домашніх тварин особливостей утримання та годівлі їх улюблениів часто призводить до різкого збільшення кількості захворювань органів травної системи, а саме печінки. Печінкова недостатність не має чітких клінічних ознак, а зміни в показниках лабораторних досліджень вказують на порушення лише окремих ї функиій. Клінічні симптоми в таких випадках можуть мати спільні риси, а гепаточелюлярна недостатність не відображається в характері макро- $i$ мікроскопічних змін у органі. $У$ ветеринарній медицині немає загальноприйнятої класифікації захворювань печінки для тварин різних видів. У собак та котів виділяють такі захворювання печінки: гепатит, гепатодистрофію, цироз, пухлини, захворювання жовчовидільних шляхів. Більшість наведених у спеціальній літературі класифікацій не враховує анатомо-фізіологічних особливостей гепатобіліарної системи домашніх котів, тому не в повній мірі застосовується в повсякденній роботі лікаря ветеринарної медииини. У зв'язку з циим, до теперішнього часу науковий пошук у даному напрямі є актуальним.

Ключові слова: ЗАХВОРЮВАННЯ ПЕЧІНКИ, ГЕПАТОДИСТРОФІЯ, ТВАРИНИ, ПОРУШЕННЯ ОБМІНУ РЕЧОВИН.
\end{abstract}

Упродовж останніх десятиліть у клінічній ветеринарній медицині світу існує значна зацікавленість щодо вивчення захворювань дрібних домашніх тварин, зокрема внутрішньої патології. Поряд з тим, жителі міст утримують не лише різноманітні породи котів та собак, але й екзотичних тварин. Незнання власниками домашніх тварин особливостей утримання їх улюбленців та годівлі часто призводить до різкого збільшення захворювань органів травної системи, а саме печінки.

Недостатність функції печінки. За даними досліджень А. М. Боброва зі співавт., печінкова недостатність не має чітких клінічних ознак, а зміни в показниках лабораторних досліджень вказують на порушення лише окремих іiі функцій [1].

Водночас, А. І. Казанов зі співав. (2008) [2] зазначав, що гепатоцелюлярна недостатність може виникати і за гострого, і за хронічного перебігу захворювань печінки. Клінічні симптоми в таких випадках можуть мати спільні риси. Автор наголошує, що гепатоцелюлярна недостатність не відображається в характері макро- і мікроскопічних змін у печінці.

Відомі класифікації недостатності функцій печінки базуються на різних принципах 3 урахуванням різноманітних тестів.

У роботах І. Д. Мансурової [3] і Х. Х. Мансурова [4] детально наведена класифікація функціональної недостатності печінки, згідно якої автори виділяють в її розвитку два періоди:

${ }^{12}$ Науковий керівник - Н. С. Канівець, к. вет. н., доцент 
1) період компенсації (відсутні функціональні порушення, незважаючи на структурні зміни печінки);

2) недостатність печінки (проявляється біохімічними, гемодинамічними та окремими клінічними симптомами).

Окрім того автори виділяють чотири форми функціональної печінкової недостатності: 3 переважними екскреторними порушеннями; 3 васкулярними порушеннями; 3 переважно клітинно-печінковими порушеннями; зміману недостатність печінки. Кожна з цих форм має ще по три-чотири ступені порушень $[3,4]$.

Однак, наведена вище класифікація зайве деталізована, громіздка, вимагає виконання складних тестів. На практиці це себе не виправдовує, тому й не застосовується в повсякденній роботі лікаря ветеринарної медицини. У зв'язку з цим, до теперішнього часу науковий пошук у даному напрямі триває, що підтверджується значною кількістю класифікацій печінкової недостатності.

Патологія печінки досить поширена серед сільськогосподарських і дрібних домашніх тварин. За даними різних науковців, серед внутрішніх хвороб захворювання печінки займають від 5 до 50,8 \% [5, 6]. Діагностують гепатит, гепатодистрофію, цироз, абсцеси печінки, холецистит і жовчнокам'яну хворобу $[4,6]$.

Не дивлячись на значні успіхи у вивченні хвороб печінки, у ветеринарній медицині немає загальноприйнятої класифікації їх для тварин різних видів, зокрема для котів. У собак, Б. В. Уша виділив такі захворювання печінки: гепатит, гепатодистрофія, цироз, пухлини, захворювання жовчовидільних шляхів [7]. Дану класифікацію застосовують і для домашніх котів.

Гепатum - запалення печінки дифузного характеру, що супроводжується ексудативними i проліферативними процесами у стромі органа, альтеративними (дистрофічними, некротичними й атрофічними) змінами гепатоцитів, а також порушенням обміну речовин, функцій нервової, серцево-судинної і травної систем [8].

За етіологією розрізняють гепатит: інфекційний (виникає внаслідок захворювання тварин на сальмонельоз, клостридіоз, лептоспіроз тощо); інвазійний (захворювання котів на бабезіоз, лейшманіоз, токсоплазмоз); токсичний (отруєння тварин карбону тетрахлоридом та сполуками важких металів, застосування гепатотоксичних препаратів: антибіотиків тетрациклінового ряду, сульфаніламідів, аміназину, фенобарбіталу, похідних стероїдів, а також внаслідок дії на печінку ендотоксинів; реактивний (на фоні захворювань матки, підшлункової залози, шлунково-кишкового тракту) [9-10].

Розвиток гепатиту провокує виникнення печінкової недостатності, розладів обміну речовин (білків, жирів, вуглеводів, вітамінів та мінералів). У разі порушення білкового обміну виникає диспротеїнемія, що характеризується різким зниженням вмісту альбумінів та змінами онкотичного тиску крові. Водночас, утворення прокоагулянтів крові значно обмежується, призводячи до розладів системи згортання крові (коагулопатії). Іншим негативним проявом запалення печінки $є$ зниження процесів дезамінування амінокислот, внаслідок чого зменшується синтез сечовини та підвищується концентрація в крові аміаку $[11,12]$.

Порушення вуглеводного обміну обумовлене зміною швидкості синтезу глікогену, розщепленням його до глюкози та зниженням процесу глюконеогенезу. Такі порушення проявляються нестабільним рівнем глюкози у крові, що характеризує одну із ознак печінкової недостатності. За розладів ліпідного обміну розвивається жирова інфільтрація та дистрофія печінки, що обмежує здатність гепатоцитів до утворення ліпопротеїдів (основна транспортна форма ліпідів).

За гепатиту різної етіології порушення обміну вітамінів та мінеральних речовин супроводжуються зниженням всмоктування в кишківнику жиророзчинних вітамінів, зменшенням здатності клітин печінки трансформувати вітаміни в біологічно активні форми, гальмуванням утворення коферментів із вітамінів [13]. Запалення печінки супроводжується 
дефіцитом Цинку і вітамінів групи В, що провокує ще більше ураження печінки, зумовлене патологічним накопиченням Купруму в печінкових клітинах [14].

Порушення захисної функції печінки у разі розвитку гепатиту проявляється підвищеним рівнем токсичних продуктів обміну речовин, а інактивація клітинами Купфера мікроорганізмів та колоїдних часток знижується $[11,12]$.

Гепатодистрофія (гепатоз), об’єднує хвороби печінки, які характеризуються дистрофічними змінами паренхіми органа без ознак запалення (без вираженої мезенхімальноклітинної реакції). Ця патологія супроводжується дистрофією та некрозом гепатоцитів 3 порушенням всіх функцій печінки [8].

За даними спеціальної літератури розрізняють два перебіги гепатодистрофії: гострий і хронічний. Поряд 3 тим, за переважанням порушення обміну речовин виділяють білкову, зернисту, жирову, амілоїдну, вуглеводну та змішану дистрофії. 3 усіх гепатозів найчастіше реєструють жирову дистрофію та амілоїдоз $[8,11,14]$.

Жирова гепатодистрофія (стеатоз) характеризується накопиченням тригліцеридів у гепатоцитах за різних токсичних впливів, порушень обміну речовин і основних функцій печінки [15].

У процесі розвитку жирової дистрофії печінка втрачає глікоген, адже уражені гепатоцити не спроможні його зберігати. А візуально за мікроскопії в ділянках з різко вираженою жировою дистрофією глікоген виявляється у вигляді окремих гранул у протоплазмі печінкових клітин по периферії жирових включень [15].

Не секрет, що морфологічні зміни в печінці проявляються порушеннями їі функцій [16].

Однією із головних екскреторних функцій печінки є синтез жовчі та виділення іiі у просвіт кишечнику. За пошкодження гепатоцитів внаслідок дистрофічних змін складові жовчі проникають у кров, зростає рівень жовчних пігментів, зокрема некон'югованого білірубіну, що забарвлює тканини організму в жовтий колір (жовтяниця). Особливо інтенсивно змінює колір жирова тканина, тому захворювання має назву стеатит «жовтий жир». Розвивається холемія, яка негативно впливає на організм, зокрема серцево-судинну систему, уповільнюються серцеві скорочення, знижується артеріальний тиск $[11,12,16]$.

Прогресуючий печінковий фіброз, що призводить до цирозу печінки є одним iз наслідків хронічної патології органа. Для діагностування таких змін використовують біохімічні тести (дослідження серологічних маркерів - гіалуронової кислоти [8, 16], антиоксидантних ферментів [14]), інструментальні методи (УЗД, контрастна ультраехографія) $[14,15,17]$, пункційна біопсія $[9,11,13]$. Однак, проблема діагностування змін печінки за цирозу у котів в нашій країні залишається маловивченою, не зважаючи на значну кількість зарубіжних публікацій стосовно цього питання.

Біліарна система $є$ однією із основних транспортних систем організму, яка здійснює доставку жовчі з печінки до кишківника $[8,16]$. Основний момент розвитку захворювань біліарної системи - це здатність жовчного міхура підтримувати постійну концентрацію жовчі, тобто колоїдний стан жовчі. Таким чином вищезазначене має специфічну нозологію хвороб жовчовивідних шляхів: холецистит, холангіт, холелітіаз, дискінезію жовчного міхура й жовчних ходів тощо $[11,13,15]$.

У тварин, як і в людей, холецистит відноситься до самостійного поліетіологічного запального захворювання жовчного міхура, що не рідко, супроводжується функціональними розладами (дискінезія жовчного міхура та його сфінктерного апарату) та дисхолією (зміни фізико-хімічних властивостей і біохімічної структури жовчі).

Більшість дослідників у котів відмічають холангіогепатит (комплекс захворювань, який включає холангіт, гепатит i біліарний цироз), що зумовлено особливостями перебігу запальних процесів у цього виду тварин. Одним із характерних симптомів цієї патології у домашніх котів є підвищена агресивність [16].

Жовчнокам'яна хвороба є окремою нозологічною одиницею, однак у котів вона майже 
не реєструється. Однак причиною жовчних конкрементів вважають зміну відсоткового співвідношення фракцій ліпідів на фоні порушення концентрації жовчних кислот і лецитину, а також розвиток гострих запальних процесів у кишечнику [8].

Таким чином, слід наголосити, що захворювання гепатобіліарної системи - це надзвичайно складна патологія внутрішніх органів, яка досить часто реєструється, однак не має єдиної загальноприйнятої класифікації для тварин, щоб включало їх видові особливості, а інформативних методів діагностики та лікування тварин не розроблено.

\title{
В И С Н О В К И
}

1. Існуючі в літературі класифікації гепатобіліарної патології не забезпечують діагностичної інформативності у домашніх котів.

2. Класифікацію патології гепатобіліарної системи у домашніх котів слід розробляти 3 урахуванням анатомо-фізіологічних особливостей тварин цього виду.

\section{TO THE QUESTION OF THE DISEASES OF THE HEPATOBILARY SYSTEM IN CATS}

\author{
N. S. Kanivets, S. O. Kravchenko, T. L. Bourda, Yu. V. Maksimenko \\ Poltava State Agrarian Academy \\ 1/3, G. Skovoroda st., Poltava, 36003, Ukraine
}

\section{S U M M A R Y}

Failure by owners of pets to maintain and feed their pets often leads to a sharp increase in the number of diseases of the organs of the digestive system, namely the liver. Hepatic insufficiency has no clear clinical signs, and changes in laboratory indices indicate a violation of only some of its functions. Clinical symptoms in such cases may have common features, and hepatocellular insufficiency is not reflected in the nature of macro- and microscopic changes in the organ. Well-known researchers at one time made attempts to adapt the classification of hepatobiliary pathology, which are commonly accepted in humane medicine. However, a number of factors hinder the wide application of such classifications in veterinary medicine. Among them, such as the need for complex biochemical, histological and special tests, which, in relation to animals, are technically difficult and often impossible to implement, should be identified. In addition, the nosological structure of hepatobiliary pathology is significantly different from that of humans in terms of etiology, pathogenesis and anatomical and physiological features of animals of different species, which are caused by conditions of maintenance, feeding, and in relation to farm animals and exploitation. That is why in veterinary medicine there is no generally accepted classification of liver diseases for animals of different species. In dogs and cats, the following diseases of the liver are distinguished: hepatitis, hepatodistrophy, cirrhosis, tumors, biliary tract disease. Most of the classifications given in the special literature do not take into account the anatomical and physiological features of the hepatobiliary system of domestic cats, therefore, it is not fully used in the daily work of a veterinary medicine doctor. In this regard, to date, scientific research in this area is relevant.

Keywords: LIVER DISEASES, HEPATODYSTROPHY, ANIMALS, METABOLIC DISORDERS.

\section{К ВОПРОСУ ЗАБОЛЕВАНИЙ ГЕПАТОБИЛИАРНОЙ СИСТЕМЫ У КОШЕК}

\author{
Н. С. Канивец, С. А. Кравченко, Т. Л. Бурда, Ю. В. Максименко
}

Полтавская государственная аграрная академия

ул. Г. Сковороды, 1/3, м. Полтава, 36003, Украина 


\section{А Н Н О Т А ЦИЯ}

Несоблюдение владельцами домашних животных особенностей содержания и кормления их любимцев часто приводит к резкому увеличению количества заболеваний органов пищеварительной системы, а именно печени. Печеночная недостаточность не имеет четких клинических признаков, а изменения в показателях лабораторных исследований указывают на нарушение лишь отдельных ее функций. Клинические симптомы в таких случаях могут иметь общие черты, а гепатоцеллюлярная недостаточность не отображается в характере макро- и микроскопических изменений в органе. В ветеринарной медицине нет общепринятой классификации заболеваний печени для животных разных видов. У собак и кошек выделяют следующие заболевания печени: гепатит, гепатодистрофию, цирроз, опухоли, заболевания желчевыводящих путей. Большинство приведенных в специальной литературе классификаций не учитывает анатомо-физиологических особенностей пищеварительной системы домашних котов, поэтому не в полной мере применяется в повседневной работе врача ветеринарной медицины. В связи с этим, до настоящего времени научный поиск в этом направлении является актуальным.

КлючевЫе слова: ЗАБОЛЕВАНИЯ ПЕЧЕНИ, ГЕПАТОДИСТРОФИЯ, ЖИВОТНЫЕ, НАРУШЕНИЯ ОБМЕНА ВЕЩЕСТВ.

\section{Л I T Е P A T У P A}

1. Этиологический профиль циррозов печени с летальным исходом у стационарных больных / [А. Н. Бобров, А. И. Павлов, С. В. Плюснин и др.] // Рос. журнал гастроэнтерол., гепатол., колопроктологии. - 2006. - Т. 16, № 2. - С. 19-24.

2. Различные формы большой печеночной недостаточности: клинические особенности и исходы / [А. И. Казанов, С. В. Плюснин, А. П. Васильев и др.] // Рос. журнал гастроэнтерол., гепатол., колопроктологии. - 2008. - Т. 18, № 2. - С. 18-27.

3. Мансурова И. Д. Биохимическая характеристика функционального состояния печени в зависимости от характера ее недостаточности / И. Д. Мансурова // Материалы конф. по актуальным проблемам гастроэнтерологии : тез. докл. - Душанбе, 1969. - С. 163.

4. Мансуров X.X. Портальная гипертензия: патофизиология, класси-фикация, диагностика и тактика ведения больных / X. Х. Мансуров // Рос. журн. гастроэнтерол., гепатол., колопроктол. - 1997.- Т. VII, № 3. - С. 69-72.

5. Hepatitis with special reference to dogs. A review on the pathogenesis and infectious etiologies, including unpublished results of recent own studies / [S. Y. Boomkens, L. C. Penning, H. F. Egberink et al.] // Vet. Q. - 2004. - Vol. 26 (3). - P. 107-114.

6. Багаутдинов A. М. Морфологические изменения у свиней при гепатозе и после введения сантохина / А. М. Багаутдинов // Ветеринария. - 2008. - С. 40 - 41.

7. Уша Б. В. Болезни печени собак / Б. В. Уша, И. П. Беляков. - М. : ПАЛЬМАпресс, 2002. $-36 \mathrm{c}$.

8. Внутрішні хвороби тварин / [B. I. Левченко, I. П. Кондрахін, В.В. Влізло та ін.] ; за ред. В. І. Левченка. - Біла Церква, 2012. - Ч. 1. - 528 с.

9. Prevalence of antibody to hepatitis E virus among pet dogs in the Jiang-Zhe area of China / [J. Liu, W. Zhang, Q. Shen et al.] // Scand. J. Infect. Dis. - 2009. - Vol. 41 (4). - P. 291-295.

10. Kearns S. Infectious hepatopathies in dogs and cats / S. Kearns // Top Companion Anim. Med. - 2009. - Vol. 24 (4). - P. 189-198.

11. Primary hepatitis in dogs: a retrospective review (2002-2006) / [J. H. Poldervaart, R. P. Favier, L. C. Penning et al.] // J. Vet. Intern. Med. - 2009. - Vol. 23 (1). - P. 72-80.

12. Болезни собак и кошек. Комплексная диагностика и терапия болезней собак и кошек : учеб. пособие / [Т. К. Донская Г. Г. Щербаков, Г. В. Полушин] ; под ред. С. В. Старченкова. СПб. : Спец. литература, 2006. - 655 с. 
13. Гарбузенко Д. В. Механизмы компенсации структуры и функции печени при ее повреждении и их практическое значение / Д. В. Гарбузенко // Рос. журнал гастроэнтерол., гепатол., колопроктологии. - 2008. - Т. 18, № 6. - С. 14-22.

14. Copper-associated chronic hepatitis in Labrador Retrivers / G. Hoffman, T. S. van der Ingh, P. Bode, J. Rothuizen // J. Vet. Intern. Med. - 2006. - Vol. 20 (4). - P. 856-861.

15. Suchkova E. $V$. The functional condition of the hepato-biliary system in fatty hepatosis with concomitant diabetes mellitus / E. V. Suchkova // Eksp. Klin. Gastroenterol. - 2009. - Vol. 8. P. 26-29.

16. Mato J. M. Methionine metabolism and liver disease / J. M. Mato, M. L. Martinez-Chantar, S. C. Lu // Annu. Rev. Nutr. - 2008. - Vol. 8. - P. 273-293.

17. Локес П. І. Ультразвукова діагностика хвороб дрібних тварин / П. І. Локес, В. Г. Стовба, Л. П. Каришева. - Полтава : ФОП Говоров С. В., 2007. - 128 с.

\section{References}

1. Etiologicheskiy profil tsirrozov pecheni s letalnym iskhodom u statsionarnykh bolnykh / [A. N. Bobrov, A. I. Pavlov, S. V. Plyusnin i dr.] // Ros. zhurnal gastroenterol., gepatol., koloproktologii. - 2006. - T. 16, № 2. - S. 19-24. [in Russian]

2. Razlichnyye formy bolshoy pechenochnoy nedostatochnosti: klinicheskiye osobennosti i iskhody / [A. I. Kazanov, S. V. Plyusnin, A. P. Vasilyev i dr.] // Ros. zhurnal gastroenterol., gepatol., koloproktologii. - 2008. - T. 18, № 2. - S. 18-27. [in Russian]

3. Mansurova I. D. Biokhimicheskaya kharakteristika funktsional'nogo sostoyaniya pecheni v zavisimosti ot kharaktera yeye nedostatochnosti / I. D. Mansurova // Materialy konf. po aktual'nym problemam gastroenterologii : tez. dokl. - Dushanbe, 1969. - S. 163. [in Russian]

4. Mansurov KH. KH. Portal'naya gipertenziya: patofiziologiya, klassi-fikatsiya, diagnostika i taktika vedeniya bol'nykh / KH. KH. Mansurov // Ros. zhurn. gastroenterol., gepatol., koloproktol. - 1997.- T. VII, № 3. - S. 69-72. [in Russian]

5. Hepatitis with special reference to dogs. A review on the pathogenesis and infectious etiologies, including unpublished results of recent own studies / [S. Y. Boomkens, L. C. Penning, H. F. Egberink et al.] // Vet. Q. - 2004. - Vol. 26 (3). - P. 107-114.

6. Bagautdinov A. M. Morfologicheskiye izmeneniya u sviney pri gepatoze i posle vvedeniya santokhina / A. M. Bagautdinov // Veterinariya. - 2008. - S. 40 - 41. [in Russian]

7. Usha B. V. Bolezni pecheni sobak / B. V. Usha, I. P. Belyakov. - M. : PAL'MApress, 2002. -36 s. [in Russian]

8. Vnutrishni khvoroby tvaryn / [V. I. Levchenko, I. P. Kondrakhin, V.V. Vlizlo ta in.] ; za red. V. I. Levchenka. - Bila Tserkva, 2012. - CH. 1. - 528 s. [in Ukrainian]

9. Prevalence of antibody to hepatitis E virus among pet dogs in the Jiang-Zhe area of China / [J. Liu, W. Zhang, Q. Shen et al.] // Scand. J. Infect. Dis. - 2009. - Vol. 41 (4). - P. 291-295.

10. Kearns S. Infectious hepatopathies in dogs and cats / S. Kearns // Top Companion Anim. Med. -2009. - Vol. 24 (4). - P. 189-198.

11. Primary hepatitis in dogs: a retrospective review (2002-2006) / [J. H. Poldervaart,
[ R. P. Favier, L. C. Penning et al.] // J. Vet. Intern. Med. - 2009. - Vol. 23 (1). - P. 72-80.

12. Bolezni sobak i koshek. Kompleksnaya diagnostika i terapiya bolezney sobak i koshek : ucheb. posobiye / [T. K. Donskaya G. G. Shcherbakov, G. V. Polushin]; pod red. S. V. Starchenkova. $-\mathrm{SPb}$. : Spets. literatura, 2006. - 655 s. [in Russian]

13. Garbuzenko D. V. Mekhanizmy kompensatsii struktury i funktsii pecheni pri yeye povrezhdenii i ikh prakticheskoye znacheniye / D. V. Garbuzenko // Ros. zhurnal gastroenterol., gepatol., koloproktologii. - 2008. - T. 18, № 6. - S. 14-22/ [in Russian]

14. Copper-associated chronic hepatitis in Labrador Retrivers / G. Hoffman, T. S. van der Ingh, P. Bode, J. Rothuizen // J. Vet. Intern. Med. - 2006. - Vol. 20 (4). - P. 856-861. 
15. Suchkova E. V. The functional condition of the hepato-biliary system in fatty hepatosis with concomitant diabetes mellitus / E. V. Suchkova // Eksp. Klin. Gastroenterol. - 2009. - Vol. 8. - P. 2629.

16. Mato J. M. Methionine metabolism and liver disease / J. M. Mato, M. L. Martinez-Chantar, S. C. Lu // Annu. Rev. Nutr. - 2008. - Vol. 8. - P. 273-293.

17. Lokes P. I. Ultrazvukova diahnostyka chvorob tvaryn / P. I. Lokes, V. H. Stovba, L. P. Karysheva. - Poltava : FOP Hovorov S. V., 2007. - 128 s. [in Ukrainian].

Рецензент - Н. І. Дмитренко, к. вет. н., доцент, Полтавська державна аграрна академія.

УДК 619:631.95:631.461:648.6:614.48

doi: $10.36359 /$ scivp.2019-20-2.56

\title{
АНАЛІЗ РИНКУ ДЕЗІНФІКУЮЧИХ ЗАСОБІВ В УКРАЇНІ
}

\author{
O. I. Касяненко, д-р вет. наук, професор, \\ А. В. Березовський, д-р вет. наук, професор, \\ С. М. Касяненко, аспірант, \\ Р. В. Долбоносова, канд. вет. наук
}

Сумський національний аграрний університет, вул. Герасима Кондратьєва, 160, м. Суми, 40021, Україна

У статті наведені результати аналізу сучасного ринку дезінфікуючих засобів за активно діючими речовинами. На основі даних державного реєстру ветеринарних препаратів, кормових добавок, готових кормів та преміксів щодо зареєстрованих дезінфікуючих засобів та їх рецептур встановлено, щуо кількість препаратів для дезінфекції $i$ санації об'єктів ветеринарно-санітарного нагляду понад 200 найменувань, в тому числі вітчизняного $i$ зарубіжного виробництва. Найбільща частка засобів представлена пінними $i$ безпінними лужними засобами - 31,43 \%, пінні і безпінні кислотні засоби - 22,86 \%, дезінфектанти на основі четвертинних амонійних сполук (ЧАС) - 15,71\%, спиртові- 6, 19\%, кисневмісні дезінфектанти - 5,24\%, гуанідинові-4,76\%, засоби на основі альдегідів - 4,76\%, хлорвмісні засоби - 4,29\%. Асортимент засобів дезінфекиї на вітчизняному ринку має тенденцію до збільшення.

Ключові слова: ДЕЗІНФІКУЮЧІ ЗАСОБИ, АКТИВНО ДІЮЧІ РЕЧОВИНИ, ПАТОГЕНИ, ЗАСТОСУВАННЯ, ЕФЕКТИВНІСТЬ.

Актуальним питанням сучасної ветеринарної медицини є розробка та застосування біологічно ефективних, екологічно безпечних i конкурентоспроможних дезінфікуючих засобів. Застосування дезінфектантів є одним із пріоритетних заходів ветеринарно-гігієнічних програм профілактики та ліквідації інфекційних хвороб тварин та птиці $[3-5,8]$.

Згідно із Законом України «Про основні принципи та вимоги до безпечності та якості харчових продуктів» (в редакції Закону № 1602-VII від 22.07.2014), II. Ст. 8 державна політика у сфері безпечності та якості харчових продуктів грунтується на здійсненні державного контролю за впровадженням постійно діючих процедур, заснованих на принципах НАССР [2]. Обов'язкове впровадження системи аналізу ризиків та контролю безпечності продуктів 